\title{
Interplay Between Tumor Necrosis Factor- $\alpha$, Insulin Resistance and Type 2 Diabetes Mellitus in Chronic Hepatitis C Egyptian Patients
}

\author{
Mostafa S Elkady ${ }^{1}$, Maha Z Omar', Mona M Elbehisy ${ }^{2}$, Mohamed A \\ Mohamed $^{3}$ \\ ${ }^{1}$ Department of Hepatology, Gastroenterology and Infectious Diseases, Benha University, Egypt \\ ${ }^{2}$ Department of Clinical Pathology, Benha University, Egypt. \\ ${ }^{3}$ New General Mansoura Hospital, Egypt.
}

\section{Corresponding \\ Author: \\ Mohamad Atef \\ Mohamad}

Mobile:+2010020366

60

E mail:

dr_mamahfouz@yaho o.com

Key words: TNF- $\alpha$, insulin resistance, $, D M, H C V$
Background and study aim : Hepatitis C is a disease with significant global impact, it is the most common cause of chronic liver diseases, and in addition it causes insulin resistance (IR) leading to increase the risk of type 2 diabetes mellitus (DM). This current study aimed to assess the relationship between serum tumor necrosis factor $-\alpha$ $(\mathrm{TNF}-\alpha)$, insulin resistance (IR) and type $2 \mathrm{DM}$ in patients $\mathrm{HCV}$.

Patients and Methods: The study cohort consisted of 91 subjects stratified into 4 groups; Group (I): Included $25 \mathrm{HCV}$ patients without DM, Group (II): Included $25 \mathrm{HCV}$ diabetic patients, Group (III): Included 25 diabetic patients without HCV infection and group (IV): Included 16 healthy subjects serving as a control group. All patients were subjected to full history taking, thorough clinical examination and estimation of body mass index (BMI). Anti-HCV Ab was detected by the 3rd generation (ELISA) test and was confirmed by PCR. Assessment of fasting plasma insulin level (FBI) and TNF- $\alpha$ were done by ELISA test, while assessment of the insulin resistance was estimated by

\section{INTRODUCTION}

Hepatitis $\mathrm{C}$ virus (HCV) infection is a major cause of chronic liver disease, affecting $3 \%$ of the world's population, both HCV liver disease and type 2 diabetes are two already prevalent diseases that will probably continue to increase in the next decades [1]. Chronic hepatitis $\mathrm{C}$ comprises extra hepatic features as, thyroiditis, arthritis, essential mixed cryoglobulinemia and other immunological diseases [2]. During the last decade, it has been hypothesized that diabetes could be one more of these extra hepatic conditions attributable to $\mathrm{HCV}$ infection.
Homeostatic Model Assessment (HOMAIR).

Results: Higher mean levels of FBS, $2 \mathrm{hr}$ (2HPP) and fasting plasma insulin (FSI) were detected in group II $(\mathrm{HCV}+\mathrm{DM})$ compared to other groups with statistically significant differences between all the studied groups ( $\mathrm{P}$ value <0.001), consequently HCV diabetic patients were found to have significant higher IR than HCV patients without DM, diabetic patients alone and control group ( $\mathrm{P}$ value $<0.001)$. Furthermore, there was highly statistically significant differences between all studied groups as regard level of TNF- $\alpha$ ( $\mathrm{P}$ value $<0.001)$ with higher mean level in group I (HCV group). Insignificant difference in level of TNF- $\alpha$ in HCV patients with or without IR ( $\mathrm{P}$ value $=0.072)$. Insignificant positive correlation between HOMA-IR and TNF$\alpha(\mathrm{P}$ value $=0.63)$.

Conclusion: Chronic HCV patients have significantly elevated fasting plasma insulin level, TNF- $\alpha$ and significant IR and there was insignificant correlation between HOMA-IR and TNF- $\alpha$.

This raises the intriguing question of whether the rise in $\mathrm{HCV}$ infection is contributing to the increasing prevalence of type 2 diabetes [3].

The specific mechanisms involved in the pathogenesis of diabetes associated with $\mathrm{HCV}$ infection remain to be elucidated; it seems that insulin resistance (IR) may play an essential role [4]. Two types of insulin resistance could be defined in patients with chronic hepatitis C: "metabolic" insulin resistance and "viral" insulin resistance [5]. Insulin secretion increases when insulin sensitivity decreases until a threshold in which insulin secretion 
did not induce improvement in insulin sensitivity, and diabetic state emerges $[\mathbf{5 , 6 ]}$. The development of IR in chronic hepatitis $\mathrm{C}$ infected patients is due to virus-specific alteration in host metabolism as chronic low-grade activation of the immune system may play a role in the pathogenesis of IR and DM. In chronic hepatitis $\mathrm{C}$ infection, markers of inflammation, like, tumor necrosis factor- $\alpha$ $(\mathrm{TNF}-\alpha)$ may play an essential role in the pathogenesis of IR as TNF- $\alpha$ represents an integral component of the inflammatory response to HCV infection [7]. So, HCV, insulin resistance and type 2 diabetes mellitus are associated to an extent that cannot be merely explained by chance, which suggests that HCV interferes with glucose metabolism, directly (through one or more of its proteins) and/or indirectly (by modulating the production of specific cytokines, like TNF- $\alpha$ [8]. In this study we aimed to assess the link between serum level of TNF- $\alpha$, IR and DM in chronic $\mathrm{HCV}$ patients.

\section{PATIENTS AND METHODS}

This prospective study was conducted on 91 subjects (54 males and 37 females attending the New General Mansoura Hospital during the period from February 2014 to August 2014. They were divided into 4 groups: Group I; included $25 \mathrm{HCV}$ patients without Diabetes mellitus. Group II; included $25 \mathrm{HCV}$ diabetic patients. Group III; included 25 diabetic patients without $\mathrm{HCV}$ infection. Group IV; Included 16 healthy subjects serving as a control group. The inclusion criteria was adult patients tested positive for $\mathrm{HCV}$ antibody and HCV RNA by PCR, whereas patients with other etiologies of liver disease, patients with decompensated cirrhosis, hepatocellular carcinoma or type I diabetes mellitus, patients previously treated with pegylated interferon/ribavirin therapy were excluded.

\section{Methodology:}

All patients were subjected to the following: Full History taking and Clinical examination, laboratory assessment (ALT, AST, total and direct bilirubin, albumin, prothrombin time and creatinine) and imaging (ultrasound), data during the previous 3 months were revised, check for diabetes mellitus (Fasting and postprandial blood sugar to diagnose diabetic and non-diabetic groups according WHO guidelines (FBS $126 \mathrm{mg} / \mathrm{dl}$, 2HPP 200mg/dl and/ or other co-morbid illness while assessment of fasting plasma insulin level and TNF- $\alpha$ were done by ELISA method. Detection of anti HCV was done by the 3rd generation ELISA test and confirmed by quantitative polymerase chain reaction (PCR). Assessment of the insulin resistance state was done by Homeostatic Model Assessment (HOMA-IR). Which calculated as follow: FPG $\mathrm{mg} / \mathrm{dl} \times \mathrm{FSI} \mathrm{uU} / \div \mathrm{ml} 405$.Where FPG is fasting plasma glucose in $\mathrm{mg} / \mathrm{dl}$, while FSI is fasting serum insulin in $\mu \mathrm{U} / \mathrm{ml}$. The homeostatic model assessment (HOMA) is a method used to quantify insulin resistance and beta-cell function from fasting insulin and insulin concentration [9]. A value greater than 3 indicates insulin resistance [10].

\section{Statistical Analysis:}

The collected data were tabulated and analyzed using SPSS (Statistical package for social science) program version 17 software. All data are expressed as the mean $\pm \mathrm{SD}$. For statistical analysis, we used analysis of variance (ANOVA) for repeated measurements followed by post hoc comparison with the Dennett procedure. The differences between the two groups were analyzed by Student's unpaired t-test. Pearson's correlation study was done between two quantitative variables. A probability value ( $\mathrm{p}$-value) less than 0.05 was considered statistically significant.

\section{RESULTS}

There was no statistically significant differences between all the studied groups as regard age, sex and BMI, while the majority of studied groups were males with higher mean age was in (HCV diabetic patients) group II (45.52 \pm 8.77 years $)$ (Table 1). Regarding laboratory finding there was highly statistically significant differences between all studied groups as regard platelet count (p-value <0.001), ALT level ( $\mathrm{p}$-value <0.001), AST level (p-value $<0.001$ ), Serum total bilirubin ( $\mathrm{p}$-value $=0.006)$, Serum albumin $(\mathrm{p}$-value $=0.005)$ PT (p-value <0.001) and INR (p- value $=0.001$ ), In contrast there is no statistically significant differences between group I (HCV Patients) and group II (HCV diabetic patients) as regard viral load level (Table 2). Level of serum fasting insulin was significantly lower in patients with DM alone compared to HCV patients alone and patients with HCV and DM $(8.08 \pm 12.46,15.29 \pm$ $26.76,32.46 \pm 26.34$ respectively) with $P$ value $<0.001$ and higher mean levels of fasting blood glucose, 2 hours post prandial blood glucose were in Group II (HCV diabetic patients) than other studied groups, with highly statistically significant differences between all studied groups 
( $\mathrm{p}$ value <0.001) for each studied parameter (Table 3). Regarding the level of serum TNF- $\alpha$ among the studied groups it was higher in HCV patients alone followed by patients with $\mathrm{HCV}$ and DM then patients with DM alone then control group $(59.41 \pm 13.61,51.39 \pm 16.54,43.49$ $\pm 15.32,28.64 \pm 14.94$ respectively) with highly statistically significant differences between them (P value < 0.001) (Fig. 1).

IR was significantly higher among HCV patients with DM compared to patients with DM alone and $\mathrm{HCV}$ patients alone and control group $(13.00 \pm 12.40,6.58 \pm 12.52,1.77 \pm 2.99,1.19 \pm 1.20$ respectively) $\mathrm{P}$ value $<0.001$ (Fig. 2). The majority of patients of group II had HOMA-IR > 3 [18 patients (72\%)] (total number of HOMA-IR $>3$ was 31 in studied groups) with highly statistically significant differences between studied groups (p- value <0.001). FSI level was significantly higher in patients with IR than in patients without IR $(38.84 \pm 28.11,4.79 \pm 3.40$ respectively) $\mathrm{P}$ value $<0.001$. Also level of both FBS and 2 HPP was statistically higher in patients with IR than in patients without IR(P value <0.001). Mean level of HOMA-IR was significantly higher in patients with IR than in patients without IR $(15.54 \pm 13.52$, $1.18 \pm 0.84$ respectively) $\mathrm{P}$ value $<0.001$. While there was no significant differences in level of TNF- $\alpha$ in two groups $(\mathrm{P}$ value $=0.336$ ) (Table 4). In comparison between HCV patients with IR and HCV patients without IR (total No $=50$ ). Higher mean levels of FBS, 2 HPP, FSI and HOMA-IR was in HCV patients with IR (P value $<0.001)$. While level of TNF- $\alpha$ was higher in $\mathrm{HCV}$ patients without IR than HCV patients with IR with no significant differences $(\mathrm{P}$ value $=$ 0.072). So in this study TNF- $\alpha$ appears not to play role in IR in HCV patients (Table 5). IR in $\mathrm{HCV}$ patients showed insignificant positive correlation with age, BMI, TNF- $\alpha(\mathrm{P}$ value $=$ 0.096, 0.477, 0.639 respectively), but there was significant positive correlation between HOMAIR in HCV patients and both FBS and FSI (P value $=0.004,<0.001$ respectively) (Table 6).

Table (1): Demographic Criteria of studied groups.

\begin{tabular}{|l|c|c|c|c|c|c|}
\hline \multicolumn{1}{|c|}{ Variable } & $\begin{array}{c}\text { Group (I) } \\
\text { HCV } \\
(\mathbf{n = 2 5})\end{array}$ & $\begin{array}{c}\text { Group (II) } \\
\text { HCV\&DM } \\
(\mathbf{n = 2 5})\end{array}$ & $\begin{array}{c}\text { Group (III) } \\
\text { DM } \\
(\mathbf{n = 2 5})\end{array}$ & $\begin{array}{c}\text { Group (IV) } \\
\text { Control } \\
(\mathbf{n = 1 6})\end{array}$ & Test & $\begin{array}{c}\text { P- } \\
\text { value }\end{array}$ \\
\hline Age(Mean $\pm \mathrm{SD})$ & $42.88 \pm 11.44$ & $45.52 \pm 8.77$ & $43.28 \pm 10.35$ & $40.69 \pm 10.35$ & 0.749 & 0.526 \\
\hline $\begin{array}{l}\text { Sex:(No\%) } \\
\text { Male }\end{array}$ & $15(60 \%)$ & $14(56 \%)$ & $14(56 \%)$ & $9(56.3 \%)$ & $0.115^{\#}$ & 0.990 \\
Female & $10(40 \%)$ & $11(44 \%)$ & $11(44 \%)$ & $7(43.8 \%)$ & & 0.804 \\
\hline BMI $\left(\mathrm{Kg} / \mathrm{m}^{2}\right)$ & $27.42 \pm 4.95$ & $28.45 \pm 4.69$ & $28.32 \pm 5.92$ & $27.19 \pm 4.61$ & 0.330 & 0.804 \\
\hline
\end{tabular}

Table (2): Comparison between studied groups as regard laboratory findings (CBC, Liver profile tests, serum creatinine and PCR for HCVRNA).

\begin{tabular}{|l|c|c|c|c|c|c|}
\hline \multicolumn{1}{|c|}{ Variable } & $\begin{array}{c}\text { Group (I) } \\
\text { HCV } \\
(\mathbf{n = 2 5})\end{array}$ & $\begin{array}{c}\text { Group (II) } \\
\text { HCV\&DM } \\
(\mathbf{n = 2 5 )}\end{array}$ & $\begin{array}{c}\text { Group (III) } \\
\text { DM } \\
(\mathbf{n = 2 5})\end{array}$ & $\begin{array}{c}\text { Group (IV) } \\
\text { Control } \\
(\mathbf{n = 1 6})\end{array}$ & Test & $\begin{array}{c}\text { P- } \\
\text { value }\end{array}$ \\
\hline $\mathrm{Hb}(\mathrm{gm} / \mathrm{dl})$ & $12.21 \pm 1.99$ & $12.35 \pm 1.84$ & $13.22 \pm 2.63$ & $12.97 \pm 2.27$ & 1.163 & 0.329 \\
\hline WBCS(c/mm3) & $6.34 \pm 2.25$ & $7.27 \pm 2.06$ & $6.90 \pm 2.10$ & $6.83 \pm 2.41$ & 0.759 & 0.520 \\
\hline PLT(c/mm3) & $174.60 \pm 80.61$ & $156.84 \pm 56.18$ & $220.12 \pm 46.26$ & $266.50 \pm 75.46$ & 11.28 & $<0.001^{*}$ \\
\hline ALT(U/L) & $44.04 \pm 26.05$ & $48.32 \pm 22.04$ & $30.76 \pm 15.20$ & $22.50 \pm 10.53$ & 7.198 & $<0.001^{*}$ \\
\hline AST(U/L) & $47.88 \pm 29.38$ & $44.04 \pm 22.16$ & $29.44 \pm 16.87$ & $18.31 \pm 7.80$ & 8.067 & $<0.001^{*}$ \\
\hline Total Bilirubin (mg/dl) & $1.12 \pm 0.49$ & $1.08 \pm 0.35$ & $0.86 \pm 0.17$ & $0.81 \pm 0.21$ & 4.456 & $0.006^{*}$ \\
\hline Direct Bilirubin (mg/dl) & $0.24 \pm 0.14$ & $0.25 \pm 0.12$ & $0.21 \pm 0.07$ & $0.20 \pm 0.08$ & 1.181 & 0.322 \\
\hline S. Albumin (gm/dl) & $3.95 \pm 0.73$ & $4.04 \pm 0.54$ & $4.45 \pm 0.40$ & $4.34 \pm 0.40$ & 4.511 & $0.005^{*}$ \\
\hline PT (sec) & $14.81 \pm 2.22$ & $14.36 \pm 1.57$ & $13.22 \pm .29$ & $13.14 \pm 0.23$ & 7.483 & $<0.001^{*}$ \\
\hline INR & $1.24 \pm 0.29$ & $1.16 \pm 0.19$ & $1.05 \pm 0.08$ & $1.03 \pm 0.05$ & 6.451 & $0.001^{*}$ \\
\hline S. Creatinine (mg/dl) & $0.79 \pm 0.24$ & $0.82 \pm 0.22$ & $0.87 \pm 0.27$ & $0.78 \pm 0.17$ & 0.662 & 0.577 \\
\hline Viral load PCR (IU/ml) & $1176385.20 \pm$ & $1532572.40 \pm$ & 0 & 0 & 311.5 & 0.985 \\
\hline
\end{tabular}


Table (3): Comparison between studied groups as regard fasting blood glucose level, 2hours postprandial blood glucose level and serum fasting insulin level

\begin{tabular}{|l|c|c|c|c|c|c|}
\hline \multicolumn{1}{|c|}{ Variable } & $\begin{array}{c}\text { Group (I) } \\
\text { HCV } \\
(\mathbf{n = 2 5})\end{array}$ & $\begin{array}{c}\text { Group (II) } \\
\text { HCV\&DM } \\
(\mathbf{n = 2 5})\end{array}$ & $\begin{array}{c}\text { Group (III) } \\
\text { DM } \\
(\mathbf{n = 2 5})\end{array}$ & $\begin{array}{c}\text { Group (IV) } \\
\text { Control } \\
(\mathbf{n = 1 6})\end{array}$ & Test & $\begin{array}{c}\text { P- } \\
\text { value }\end{array}$ \\
\hline $\begin{array}{l}\text { FBS } \\
\text { N= }(70 \text { to } 110 \mathrm{mg} / \mathrm{dl})\end{array}$ & $85.24 \pm 9.83$ & $153.08 \pm 31.97$ & $143.20 \pm 39.36$ & $83.88 \pm 10.14$ & 40.633 & $<0.001^{*}$ \\
\hline $\begin{array}{l}2 \mathrm{HPP} \\
\text { N= up to }(140 \mathrm{mg} / \mathrm{dl})\end{array}$ & $121.96 \pm 14.40$ & $230.88 \pm 50.87$ & $196.96 \pm 57.53$ & $123.25 \pm 11.61$ & 39.598 & $<0.001^{*}$ \\
\hline $\begin{array}{l}\text { FSI } \\
\text { N= }(8.4-8.8 \mathrm{uU} / \mathrm{m} 1)\end{array}$ & $15.29 \pm 26.76$ & $32.46 \pm 26.34$ & $8.08 \pm 12.46$ & $5.98 \pm 6.21$ & 7.562 & $<0.001^{*}$ \\
\hline
\end{tabular}

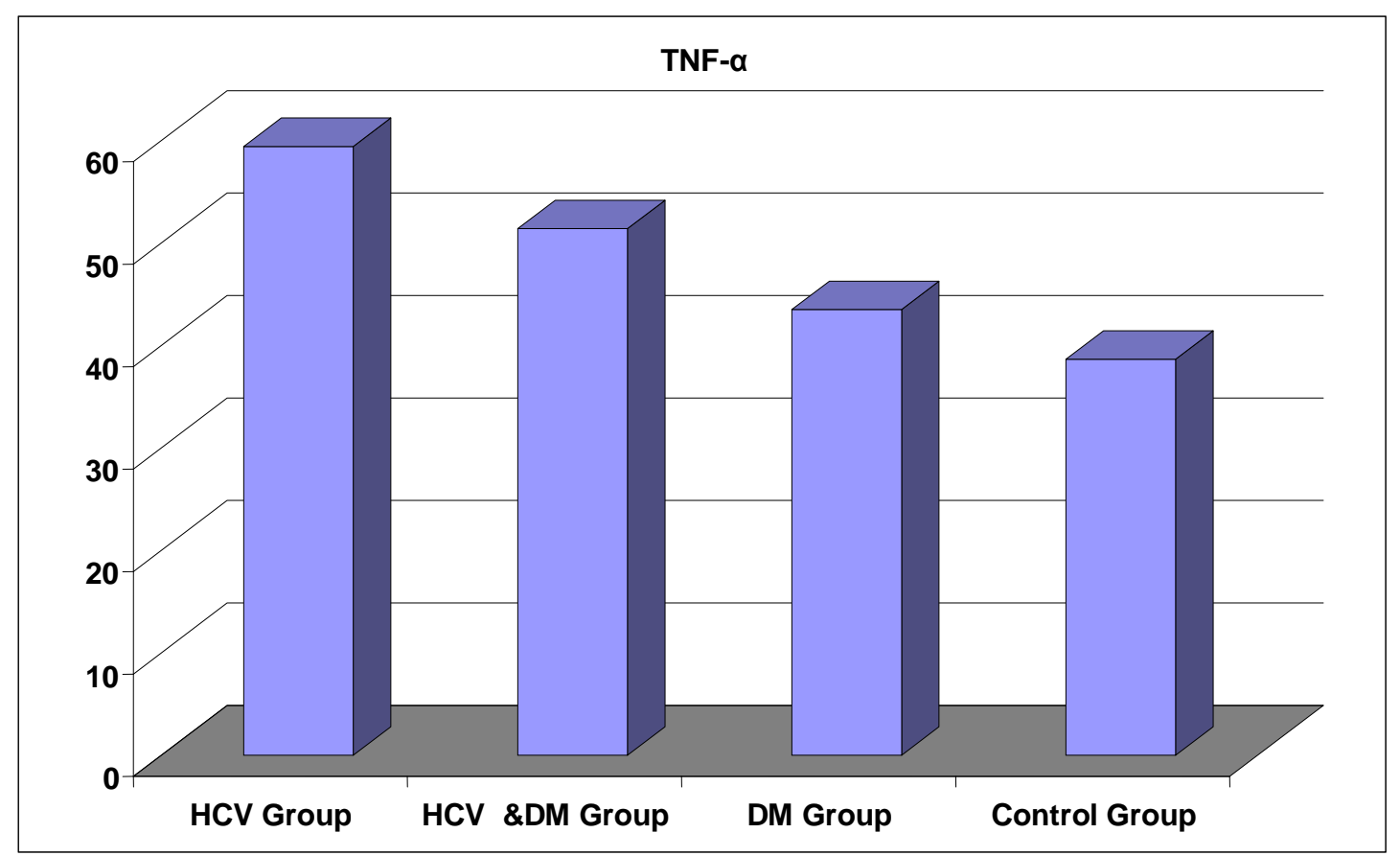

Fig. (1):Comparison between studied groups as regard Serum level of TNF- $\alpha$ 


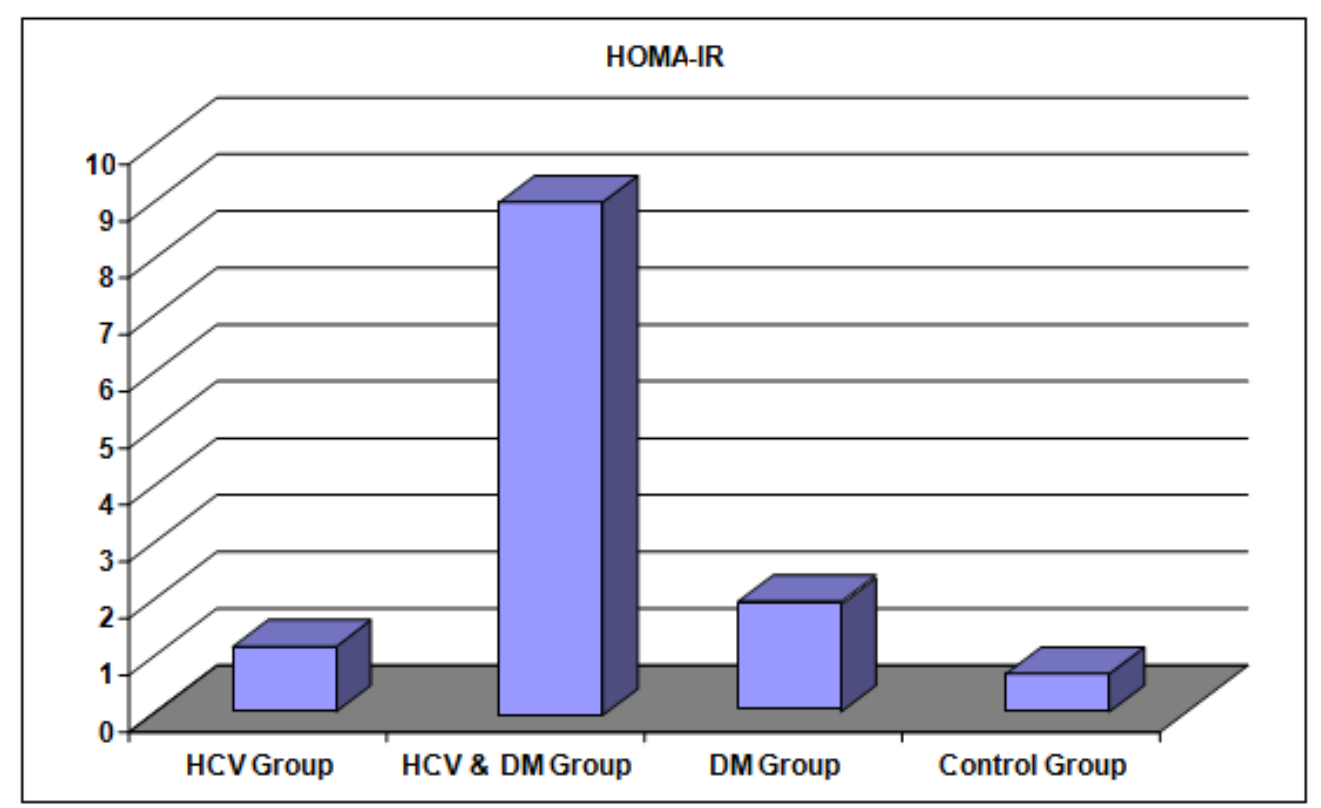

Fig. (2): Comparison between studied groups as regard HOMA-IR levels

Table (4): Comparison of patients with insulin resistance and patients without insulin resistance in studied groups as regard laboratory findings

\begin{tabular}{|l|c|c|c|c|}
\hline \multicolumn{1}{|c|}{ Variable } & $\begin{array}{c}\text { HOMA<3 } \\
(\mathbf{n = 6 0})\end{array}$ & $\begin{array}{c}\text { HOMA>3 } \\
(\mathbf{n = 3 1})\end{array}$ & test & P-value \\
\hline Age $(\mathrm{Mean} \pm \mathrm{SD})$ & $40.92 \pm 10.13$ & $48.00 \pm 8.80$ & 3.301 & $0.001^{*}$ \\
\hline BMI(Kg/m $\left.{ }^{2}\right)$ & $26.62 \pm 4.45$ & $30.40 \pm 5.30$ & 3.600 & $0.001^{*}$ \\
\hline $\mathrm{Hb}(\mathrm{gm} / \mathrm{dl})$ & $12.81 \pm 2.03$ & $12.37 \pm 2.52$ & 0.907 & 0.367 \\
\hline WBCS(c/mm3) & $6.50 \pm 2.07$ & $7.48 \pm 2.28$ & 2.065 & $0.042^{*}$ \\
\hline PLT(c/mm3) & $208.95 \pm 70.73$ & $177.94 \pm 81.03$ & 1.886 & 0.063 \\
\hline ALT(IU/dl). & $34.57 \pm 19.65$ & $44.00 \pm 25.36$ & 1.962 & 0.053 \\
\hline AST(IU/dl). & $33.37 \pm 21.98$ & $42.74 \pm 26.56$ & 1.794 & 0.076 \\
\hline Total Bilirubin $(\mathrm{mg} / \mathrm{dl})$ & $0.96 \pm 0.35$ & $1.03 \pm 0.37$ & 0.791 & 0.431 \\
\hline Direct Bilirubin $(\mathrm{mg} / \mathrm{dl})$ & $0.22 \pm 0.11$ & $0.25 \pm 0.11$ & 1.409 & 0.162 \\
\hline S. Albumin $(\mathrm{gm} / \mathrm{dl})$ & $4.24 \pm 0.59$ & $4.07 \pm 0.55$ & 1.356 & 0.178 \\
\hline PT(sec.) & $13.87 \pm 1.61$ & $14.12 \pm 1.55$ & 0.719 & 0.474 \\
\hline INR & $1.12 \pm 0.21$ & $1.15 \pm 0.19$ & 0.773 & 0.442 \\
\hline S. Creatinine $(\mathrm{mg} / \mathrm{dl})$ & $0.77 \pm 0.20$ & $0.92 \pm 0.25$ & 3.200 & $0.002^{*}$ \\
\hline FBS(mg/dl) & $102.67 \pm 31.41$ & $152.26 \pm 40.41$ & 5.965 & $<0.001^{*}$ \\
\hline 2HPP(mg/dl) & $148.93 \pm 44.23$ & $218.74 \pm 67.42$ & 5.215 & $<0.001^{*}$ \\
\hline FSI(uU/m1) & $4.79 \pm 3.40$ & $38.84 \pm 28.11$ & 6.719 & $<0.001^{*}$ \\
\hline TNF- $\alpha(\mathrm{pg} / \mathrm{ml})$ & $50.40 \pm 17.68$ & $46.81 \pm 14.84$ & 0.968 & 0.336 \\
\hline HOMA_IR & $1.18 \pm 0.84$ & $15.54 \pm 13.52$ & 5.905 & $<0.001^{*}$ \\
\hline
\end{tabular}


Table (5): Comparison of HCV patients with insulin resistance and HCV patients without insulin resistance

\begin{tabular}{|l|c|c|c|c|}
\hline \multicolumn{1}{|c|}{ Variable } & $\begin{array}{c}\text { HOMA < 3 } \\
(\mathbf{n = 2 9 )}\end{array}$ & $\begin{array}{c}\text { HOMA > 3 } \\
(\mathbf{n = 2 1})\end{array}$ & test & P-value \\
\hline Age $(\mathrm{M} \pm$ SD) & $40.79 \pm 11.02$ & $47.24 \pm 9.88$ & 2.089 & $0.048^{*}$ \\
\hline BMI $\left(\mathrm{Kg} / \mathrm{m}^{2}\right)$ & $26.20 \pm 5.05$ & $30.17 \pm 5.17$ & 2.711 & $0.009^{*}$ \\
\hline HG $(\mathrm{gm} / \mathrm{dl})$ & $12.67 \pm 2.08$ & $12.78 \pm 2.77$ & 0.161 & 0.873 \\
\hline WBCS $(\mathrm{c} / \mathrm{mm} 3)$ & $6.14 \pm 1.93$ & $7.28 \pm 2.35$ & 1.866 & 0.068 \\
\hline PLT $(\mathrm{c} / \mathrm{mm} 3)$ & $196.72 \pm 78.35$ & $198.24 \pm 55.37$ & 0.080 & 0.937 \\
\hline ALT $(\mathrm{IU} / \mathrm{dl})$. & $37.17 \pm 23.03$ & $37.71 \pm 21.43$ & 0.085 & 0.933 \\
\hline AST $(\mathrm{IU} / \mathrm{dl})$. & $38.86 \pm 25.93$ & $38.38 \pm 25.47$ & 0.065 & 0.948 \\
\hline Total Bilirubin $(\mathrm{mg} / \mathrm{dl})$ & $1.04 \pm 0.42$ & $0.92 \pm 0.32$ & 1.121 & 0.268 \\
\hline Direct Bilirubin $(\mathrm{mg} / \mathrm{dl})$ & $0.23 \pm 0.13$ & $0.22 \pm 0.09$ & 0.180 & 0.858 \\
\hline S. Albumin $(\mathrm{gm} / \mathrm{dl})$ & $4.16 \pm 0.69$ & $4.25 \pm 0.55$ & 0.469 & 0.641 \\
\hline PT $(\mathrm{sec})$. & $14.25 \pm 2.03$ & $13.69 \pm 1.27$ & 1.211 & 0.232 \\
\hline INR & $1.17 \pm 0.27$ & $1.11 \pm 0.17$ & 1.042 & 0.303 \\
\hline S. Creatinine $(\mathrm{mg} / \mathrm{dl})$ & $0.77 \pm 0.23$ & $0.91 \pm 0.27$ & 2.040 & $0.047^{*}$ \\
\hline FBS $(\mathrm{mg} / \mathrm{dl})$ & $88.03 \pm 11.57$ & $150.38 \pm 38.99$ & 7.105 & $<0.001^{*}$ \\
\hline 2HPP $(\mathrm{mg} / \mathrm{dl})$ & $125.52 \pm 17.18$ & $206.33 \pm 57.84$ & 6.208 & $<0.001^{*}$ \\
\hline FSI (uU/m1) & $5.41 \pm 3.24$ & $40.81 \pm 24.75$ & 6.515 & $<0.001^{*}$ \\
\hline TNF- $\alpha(\mathrm{pg} / \mathrm{ml})$ & $55.45 \pm 16.45$ & $45.93 \pm 15.12$ & 1.800 & 0.072 \\
\hline HOMA_IR & $1.19 \pm 0.76$ & $15.95 \pm 11.85$ & 5.698 & $<0.001^{*}$ \\
\hline
\end{tabular}

Table (6): Correlation of HOMA $>3$ in HCV patients with some studied parameters

\begin{tabular}{|l|c|c|}
\hline \multirow{2}{*}{ Variable } & \multicolumn{2}{|c|}{ HOMA_IR $>\mathbf{3}$} \\
& No (21) \\
\cline { 2 - 3 } & R (range) & P - value \\
\hline Age $(\mathrm{M} \pm \mathrm{SD})$ & 0.382 & 0.096 \\
\hline $\mathrm{BMI}\left(\mathrm{Kg} / \mathrm{m}^{2}\right)$ & 0.164 & 0.477 \\
\hline FBS $(\mathrm{mg} / \mathrm{dl})$ & 0.601 & $0.004^{*}$ \\
\hline FSI $(\mathrm{uU} / \mathrm{ml})$ & 0.933 & $<0.001^{*}$ \\
\hline $\mathrm{TNF} \alpha(\mathrm{pg} / \mathrm{ml})$ & 0.109 & 0.639 \\
\hline
\end{tabular}

\section{DISCUSSION}

Metabolic abnormalities are common in patients with hepatitis $\mathrm{C}$ virus (HCV) infection, there is considerable evidence that patients with chronic $\mathrm{HCV}$ infection are at a greater risk of developing insulin resistance (IR) and ultimately, diabetes mellitus (DM) compared with non-infected individuals or patients with hepatitis B virus (HBV) infection [11]. The pathogenic mechanisms causing DM in patients with $\mathrm{HCV}$ infection are still not well understood, although both insulin resistance and impaired insulin secretion have been considered to play an important role in the development of DM [12]. More recently, the role of tumor necrosis factor (TNF- $\alpha$ ) in the pathogenesis of DM in chronic hepatitis $\mathrm{C}$ patients has gained extensive interest [13]. TNF$\alpha$ has been shown to inhibit insulin-stimulated tyrosine phosphorylation of insulin receptor and insulin receptor substrate 1 in adipocytes, stimulate lipolysis, and increase serum-free fatty acids, leading to insulin resistance in muscle and liver, mediate hepatic insulin resistance to increase hepatic glucose production, and downregulate genes in adipocytes encoding proteins such as insulin receptor substrate 1 , glucose transporter-4, peroxisome proliferator-activated 
receptors, and adiponectin. In addition, TNF- $\alpha$ may reduce beta-cell function by direct toxic effects, further contributing to the development of DM. Some studies have shown significantly higher levels of soluble TNF- $\alpha$ receptors in diabetic $\mathrm{HCV}$ patients than in non-diabetic $\mathrm{HCV}$ patients and controls [14]. A link between chronic HCV infection, TNF- $\alpha$, and type 2 DM is an attractive hypothesis. In the present study there was no statistical significant differences between all studied groups as regard age, sex and BMI. While the majority of studied groups were males and higher mean age was in (HCV diabetic patients) group II (45.52 \pm 8.77 years). These data come in agreement with Shintani et al, [4]. Who found that the development of IR in patients with chronic HCV infection can occur early in the course of the disease and this effect appears to be independent of body weight.On other hand Petit et al, [15] reported that older age and obesity are correlated with genesis of diabetes in patients with HCV due to liver fat deposition which may contribute to insulin resistance, which in turn lead to loss of the restraining effect of insulin on hepatocyte production of glucose, leading to appear of diabetes mellitus. In the present work the mean FSI was significantly higher in $\mathrm{HCV}$ patients with $\mathrm{DM}$ compared to $\mathrm{HCV}$ patients without DM and patients with DM alone and control group ( $\mathrm{P}$ value $<0.001$ ). This results are in agreement with the results of Hassan et al, Mansour et al and Ragab et al, $[\mathbf{1 6 , 1 7 , 1 8}$. Who found the mean fasting insulin was significantly higher in patients with $\mathrm{HCV}$ and DM compared to patients with $\mathrm{HCV}$ alone and patients with DM alone ( $p<0.01, p<0.05$ and $p<0.019)$ respectively. In this study the mean level of HOMA-IR was significantly higher among $\mathrm{HCV}$ patients with DM compared to patients with DM alone, HCV patients without DM and control group ( $\mathrm{P}<0.001)$. Insulin resistance HOMA-IR $>3$ was most frequent among HCV patients with DM, followed by patients with DM alone then HCV patients alone and control group ( $\mathrm{P}<0.001)$. And overall IR was found in 31 patients of study population (34\%) and in 21 of $\mathrm{HCV}$ patients (42\%). This agreed with Mansour et al, [17], who found the same significantly higher HOMA-IR among diabetic chronic HCV patients than non-diabetic chronic HCV patients and diabetic HCV -ve patients $(\mathrm{p}<0.05)$. While they found IR in HCV patients alone is higher than patients with DM alone. On the same hand Angelica et al, [19], in the study had been carried out on 3 groups of patients: The 1st group- 17 patients with normal glucose tolerance and with chronic hepatitis $\mathrm{C}$, the 2nd group: 15 healthy patients (control group) and the 3rd group: 13 patients with chronic hepatitis $\mathrm{C}$ and type 2 diabetes.His results agreed with our results as Insulin resistance HOMA-IR >3 was most frequent among HCV patients with DM, followed by patients with $\mathrm{DM}$ alone and $\mathrm{HCV}$ patients $(\mathrm{P}=0.0147)$. Also the study by Hassan et al, and Ragheb et al, [16,18] showed that HOMA-IR was higher HCV patients with DM compared to HCV patients without DM and DM alone and healthy control group $(\mathrm{P}$ value $<0.001)$ for each in the formal study and $(\mathrm{P}=0.0003)$ in latter study. In the present study FBS, 2HPP were higher in HCV patients with DM compared to DM alone, HCV patients without DM and control group ( $\mathrm{P}$ $<0.001)$ for each of them. Also their levels in HCV patients with IR were higher than HCV patients without IR $(\mathrm{P}<0.001)$ for each. This was in agreement with Souza et al, [20]. Who showed that Patients with chronic HCV and IR had higher levels of blood glucose $(p=0.004)$, compared with patients without IR. As regarded to TNF- $\alpha$ levels among the studied group of patients, highest level of TNF- $\alpha$ found among $\mathrm{HCV}$ patients followed by patients with $\mathrm{HCV}$ with DM and the lowest level was among patients with DM alone and control group, with significant difference between studied groups ( $P$ $<0.001$ ), this finding not fully matched with most of the previous studies $[\mathbf{5 , 1 9 ]}$ that found significant elevation of level of TNF among $\mathrm{HCV}$ patients with DM and have IR in comparing with $\mathrm{HCV}$ and DM followed with HCV patients without DM followed by diabetic patients, in some studies they found levels of TNF- $\alpha$ were significantly higher in HCV with or without DM groups compared with DM alone. $(\mathrm{p}<0.001,<0.001)$ respectively $[\mathbf{2 1}, \mathbf{2 2}]$. Also Ragheb et al. [18], found the same results but without significant difference between the studied groups $(\mathrm{P}$ value $=0.17)$. In this study there was no significant difference between $\mathrm{HCV}$ patients with IR and without IR regarding TNF- $\alpha$ level $(\mathrm{P}=$ 0.07 ), and there was no significant positive correlation between TNF- $\alpha$ and IR in HCV patients $(\mathrm{P}=0.63)$, this finding was not matched with previous studies that found significant elevation of TNF among HCV patients with IR. There is an abundance of literature to suggest that adipose tissue derived cytokines (adipocytokines) may play a key role in the development of obesity-related insulin resistance, TNF, IL6 and leptin are proinflammatory cytokines that can 
directly alter glucose and lipid metabolism. Other studies found that IR seems to be the over production of TNF- $\alpha$ [5,6]. This cytokine phosphorylates serine residues of insulinreceptor substrates 1 and 2 and enhances the production of suppressor of cytokines (SOC3). The SOC-3 substance inhibits the phosphorylation of Akt and phosphatidyl inositol 3 kinase (PI3K) [23]. This finding may explained by : 1- Type 2 diabetes is associated with both insulin resistance and a deficit of insulin secretion, as well as with high levels of other proinflammatory cytokines like IL6 and leptin, this condition should be excluded when the specific effect of $\mathrm{HCV}$ is evaluated. 2- study of adiponectin, the most abundant of all the adipocytokines has an opposite effect, increasing insulin sensitivity and having anti-steatotic, antiinflammatory and antifibrotic effects must evaluated [24], 3- study of virological causes of IR (virological type of IR). The nonstructural protein $5 \mathrm{~A}$ (NS5A) of HCV plays a significant role in virus-driven IR. HCV NS5A and increased endoplasmic reticulum stress in $\mathrm{HCV}$ infection contributes to overexpression of protein phosphatase 2A (PP2A) [25,26]. HCV core protein has been reported to induce overexpression of tumor necrosis factor (TNF- $\alpha$ ) in the liver of transgenic mice and human hepatoma cell lines [20]. These factors may have direct effect in the results of this study and also small number of studied patients can lead to limitation of this study results.

\section{Funding:Non.}

\section{Conflicts of interest: None.}

Ethical approval: The study protocol was proven by ethical committee of Benha University and informed consent was obtained from all patients before participation in this study.

\section{REFERENCES}

1- Lecube A, Hernandez C, Genesca J, Simo R. Proinflammatory cytokines, insulin resistance, and insulin secretion in chronic hepatitis $\mathrm{C}$ patients: $\mathrm{A}$ case control study. Diabetes Care 2006; 29: 1096-1101.

2- Hadziyannis SJ. The spectrum of Extrahepatic manifestations in hepatitis $C$ virus infection. $J$ Virol Hepat 1997; 4: 9-28.

3- Nocente R, Ceccanti M, Bertazzoni G, Cammarota G, Silveri N, Gasbarrini G. HCV infection and extrahepatic manifestations. Hepatogeastroenterology 2003; 50: 1149-1154.
4- Shintani Y, Fujie H, Miyoshi H, Tsutsumi T, Tsukamoto K, Kimura $\mathrm{S}$ et al. Hepatitis $\mathrm{C}$ virus infection and diabetes: direst involvement of the virus in the development of insulin resistance. Gastroenterology 2004; 126: 840-848.

5- Mason AL, Lau JY, Hoang N, Qian K, Alexander GJ, Xu L, et al. Association of diabetes mellitus and chronic hepatitis $\mathrm{C}$ virus infection. Hepatology 1999; 29: 328-333.

6- Mehta SH, Brancati FL, Sulkowski MS, Strathdee SA, Szklo M. Thomas DL. Prevalence of type 2 diabetes mellitus among persons with hepatitis $\mathrm{C}$ virus infection in the United States. Hepatology 2001; 3: 1554

7- Elsammak M, Rafai W, Elsawaf A, Abdel-Fattah I, Elatti A, Ghazal A. Elevated serum tumour necrosis alpha and ferritin may contribute to insulin resistance found in HCV positive Egyptian patients. Curr Med Res Opin 2005; 21: 527-534.

8- Ahmed LS, Kotb N, El-Serogy H, El-Shazly S, Eid N. TNF- $\alpha$ and CXCL-10 Correlation with Insulin Resistance in Patients with Chronic Hepatitis C Virus Infection.The Egyptian Journal of Immunology 2010; 17 (1): 101-111.

9- Hoehn KL, Salmon AB, Hohnen-Behrens C. "Insulin resistance is a cellular antioxidant defense mechanism". Proceedings of the National Academy of Sciences of the United States of America 2009; 106 (42): 17787-92.

10- Sjöholm A, Nyström T. Endothelial inflammation in insulin resistance. Lancet 2005; 365(9459): 610-2.

11- Knobler H, Schihmanter R, Zifroni A, Fenakel G, Schattner A. Increased risk of type 2diabetes in noncirrhotic patients with chronichepatitis C virus infection. Mayo Clin Proc 2000; 75:355-9.

12- Hwang SJ, Chen LK.Chronic Hepatitis C and Diabetes Mellitus. J Chin Med Assoc 2006;69 (4): 143-145.

13- Knobler H, Zhornicky T, Sandler A, Haran N, Ashur Y, Schattner A. Tumor necrosis factor- $\alpha-$ induced insulin resistance may mediate the hepatitis $\mathrm{C}$ virus-diabetes association. Am J Gastroenterol 2003; 98:2751-6.

14- Knobler H, Schattner A. TNF- $\alpha$, chronic hepatitis C and diabetes: a novel triad. QJM 2005; 98:1-6.

15- Petit JM, Bour JB, Galland-Jos C, Minello A, Verges B, Guiquet $M$. et al.Risk factors for diabetes mellitus and early insulin resistance in chronic hepatitis C. J Hepatol 2001; 35: 279-83. 
16- Hassan WN, Mohamed MS, Ahmed EH, AbdElmageed GK, Morsy MD, Raouf AA. Tumor Necrosis Factor and Iron Overload Are Associated with Insulin Resistance in Hepatitis C in Egyptian Patients. Am. J. Biomed. Sci. 2010; 2(4):342-351.

17- Mansour H, Mohamed H, Ahmad M.C.Metabolic Implications of Hepatitis C Virus Infection and its Correlation to Steatohepatitis in Chronic Hepatitis C Patients With and Without Type 2 Diabetes. Infectious Diseases: Research and Treatment 2010; 3: 25-33.

18- Raghe MM, Hassan A A, Sheded MM, Salama B M. Relationship between Level of Serum Tumor Necrosis Factors- $\alpha$, Insulin Resistance and Type 2 Diabetes Mellitus in Chronic Hepatitis C Patients .Med. J. Cairo Univ 2013;81 (1): 457-463.

19- Angelica S. Insulin Resistance in Patients with Chronic Hepatitis C. Timisoara Medical Journal 2007; 47(4):240-244.

20- D'souza R, Sabin C.A, Foster G.R. Insulin resistance plays a significant role in liver fibrosis in chronic hepatitis $\mathrm{C}$ and in the response to antiviral therapy. Am. J. Gastroenterol 2005; 100: 1509-1515.

21- Gutierrez-Grobe Y, Ponciano Rodriguez G, Mendez-Sanchez N. Viral hepatitis infection and insulin resistance: A review of the path physiological mechanisms. Salud Publica Mex 2011; 53: 46-51.
22- Romero-Gomez M. Insulin resistance and hepatitis C. World J. Gastroenterol 2006; 7075-7080.

23- Lecube A, Hernandez C, Genescaj, Esteban JI, Jardi R, Simor R. High prevalence of glucose abnormalities in patients with hepatitis $\mathrm{C}$ virus infection: A multivariate analysis considering the liver injury. Diabetes Care 2004; 27: 1171-1175.

24- Michalczuk MT, Kappel CR, Birkhan O, Braganca AC, Alvares-da-silve MR. Clinical Study HOMA$\mathrm{AD}$ in Assessing Insulin Resistance in Lean Noncirrhotic HCV Outpatients.International Journal of Hepatology 2012; 10.1155/576584.

25- Christen V, Treves S, Duong F.H, Heim M.H. Activation of endoplasmic reticulum stress response by hepatitis viruses up-regulates protein phosphatase 2A.Hepatology 2007; 46 (2):558-65.

Georgopoulou U, Tsitoura P, Kalamvoki M, Mavromara P. The protein phosphatase 2A represents a novel cellular target for hepatitis $\mathrm{C}$ virusNS5A protein. Biochimie 2006; 88 (6): 65162.

Peer reviewer: Rashed Hasan, Professor of Tropical Medicine and Hepatogastroenterology, Faculty of Medicine, Zagazig University, Egypt. Editor: Tarik Zaher, Professor of Tropical Medicine and Hepatogastroenterology , Faculty of Medicine, Zagazig University, Egypt. 